\title{
Novel Role of Invariant Natural Killer T-cell in Glycemic Control: Regulation by human Adenovirus 36
}

\author{
Sooho Park and Jae-Hwan Nam* \\ Department of Biotechnology, The Catholic University of Korea, Bucheon, Korea
}

\begin{abstract}
Obesity is associated with a state of chronic low-grade inflammation. This abnormal inflammation state may cause metabolic dysfunction. Many studies have supported the claim that immune cells such as adipose tissue macrophage and invariant natural killer T-cells (iNKT) are related to the development of metabolic diseases like diabetes. It has recently been reported that while human adenovirus 36 (Ad36) infection is associated with human obesity, it also helps to improve the serum level of lipid factors (glycemic control). However, the detailed cellular mechanism remains unclear. This study (The Journal of Clinical Investigation, 2012;122:3343-54) showed that iNKT cell-deficient mice on a low-fat diet used as a control for high-fat diet boasted insulin resistance phenotype without adipose tissue inflammation. The results of this study offer insight into the possibility of a novel role for iNKT related to the improvement of metabolic diseases, especially insulin resistance, and hint that Ad36-induced inflammation may be associated with iNKT in adipose tissue, while also playing a role in the improvement of glycemic control.
\end{abstract}

Key Words: Adipose tissue, iNKT, Insulin resistance, Adenovirus 36

저자들은 면역학 분야의 최신 논문으로 'low-fat diet conditions에서 adipose tissue-resident iNKT cells이 직접적 으로 adipocytes와 작용하여 adipose tissue의 정상적인 기 능을 유지하며, insulin resistance를 예방한다.'라는 내용의 논문(Natural killer $\mathrm{T}$ cells in adipose tissue prevent insulin resistance) (1)을 읽고, 이에 대한 요약과 이 분야에 대한 견해를 아래와 같이 전달하고자 합니다.

\section{요 약}

비만(obesity)이 되면 Macrophage와 T-cell과 같은 다 양한 면역세포들이 지방조직(adipose tissue)으로 축적되 어 만성 염증(chronic inflammation)을 유발한다. 따라서 비만에 의해 유도되는 염증은 한 가지 면역체계에 의해
발생하는 것이 아니라 선천성면역(innate immune system) 과 후천성면역(adaptive immune system)의 상호작용이 비 이상적으로 되어 발생하게 된다. 이렇게 발생된 비이상 적 염증반응은 이상지질혈증(dyslipidemia), 심혈관질환 (cardiovascular diseases), 당뇨병(diabetes)과 같은 2차적 대 사질환의 원인이 된다고 알려져 있다.

비만의 발달과정에서 중요한 역할을 하는 다양한 면 역세포 중, invariant natural killer T-cell (iNKT)은 사람과 마 우스의 지방조직에 상대적으로 많이 분포하고 있으며, glycosphingolipid, isoglobotrihexosylceramide, glycosphingolipids와 같은 지질항원(lipid antigen)을 MHC-like glycoprotein인 CD1d를 통해 인지하여 면역반응을 촉진한다. 이 러한 면역반응은 macrophage에 의해 분비되는 monocyte chemoattractant protein-1 (MCP-1), tumor necrosis factor

Received: July 5, 2013/ Revised: July 8, 2013/ Accepted: July 10, 2013

* Corresponding author: Jae-Hwan Nam, Ph.D. Department of Biotechnology, The Catholic University of Korea, 43-1 Yeokgok 2-dong, Wonmi-gu, Bucheon, Gyeonggi-do, 420-743, Korea.

Phone: +82-2-2164-4852, Fax: +82-2-2164-4865, e-mail: jhnam@catholic.ac.kr

(a)This is an Open Access article distributed under the terms of the Creative Commons Attribution Non-Commercial License (http://creativecommons.org/license/by-nc/3.0/). 
(TNF)- $\alpha$ 와 같은 사이토카인에 의해서 유도되며, 이외에도 지방조직 내에 존재하는 T-cell에서 분비되는 RANTES (Regulated on Activation, Normal T Cell Expressed and Secreted)와 Interferon (IFN)- $\gamma$, Interleukin (IL)-4, IL-13, IL-17 과 같은 T-cell specific chemokine에 의해서도 조절된다. NKT cello이 비이상적인 기능을 가질 때, 자가면역질환 (autoimmune disease)이나 암을 유발한다고 알려져 있다. 본 논문에서는 CD1d-dependent NKT 중 하나인 invariant NKT (iNKT)가 대사질환에서 중요한 조절 요소로 작용 함을 확인하는데 주안점을 두어 서술하고 있다.

Schipper 등은 $\mathrm{CD} 1 \mathrm{~d}$ 가 결핍된 마우스를 high-fat diet (45 kcal\% fat, HFD)에 대한 대조군으로 low-fat diet (10 $\mathrm{kcal} \%$ fat, LFD)로 식이조절을 하였을 때, 지방조직 내 에 염증반응이 없음에도 불구하고 인슐린 저항성(insulin resistance)이 유발되며, 이것은 일반적으로 HFD 조건에서 발생하는 인슐린 저항성과는 다른 양상을 보인다는 것을 알아냈다. 또한 마우스와 사람의 지방조직에서 adipose tissue (AT)-resident iNKT cells에 의해 인슐린 저항성 유발 이 조절된다는 것을 증명하였으며, 이러한 인슐린 저항성 의 조절은 non-classical MHC molecules인 CD1d와의 상호 작용을 통하여 발생한다는 사실을 발견하였다. 따라서,
AT-resident iNKT cells이 adipocyte와의 상호작용을 통하여 지방조직의 정상적인 기능을 유지하는데 중요한 역할을 하고 있다는 것을 시사하고 있다 (1). 또한 이러한 결론 은 사람 아데노바이러스 36 (human adenovirus 36, Ad36) 이 지방조직에 염증을 유도하지만 인슐린 민감성(insulin sensitivity)은 오히려 증가하는 역설적 현상에 iNKT cell 이 일정 역할을 할 가능성이 있음을 말해 주고 있다.

\section{해 설}

비만이 되면 TNF- $\alpha$ 의 발현이 증가되며, 이것이 인슐 린 저항성과 밀접한 관련이 있다는 사실이 발견된 이 후 현재까지 염증반응과 면역학적 대사작용(immunometabolism)과의 관계에 대한 연구가 활발히 진행되고 있다 (2). 다양한 대사관련 조직 중, 특히 지방조직에는 $\mathrm{CD}^{+}, \mathrm{CD}^{+} \mathrm{T}$ cells과 regulatory $\mathrm{T}$ (Treg), B cells 등 많은 종 류의 면역세포들이 존재하며, 이러한 면역세포들의 불균 형이 비만 유도나 metabolic dysfunction 유발의 원인으로 알려져 있다. 최근에는 인슐린 저항성과 같은 대사질환의 원인에 대해 연구하기 위해, 이러한 지방조직에 존재하는 다양한 면역세포들에 그 초점을 맞추고 있으며, 특히

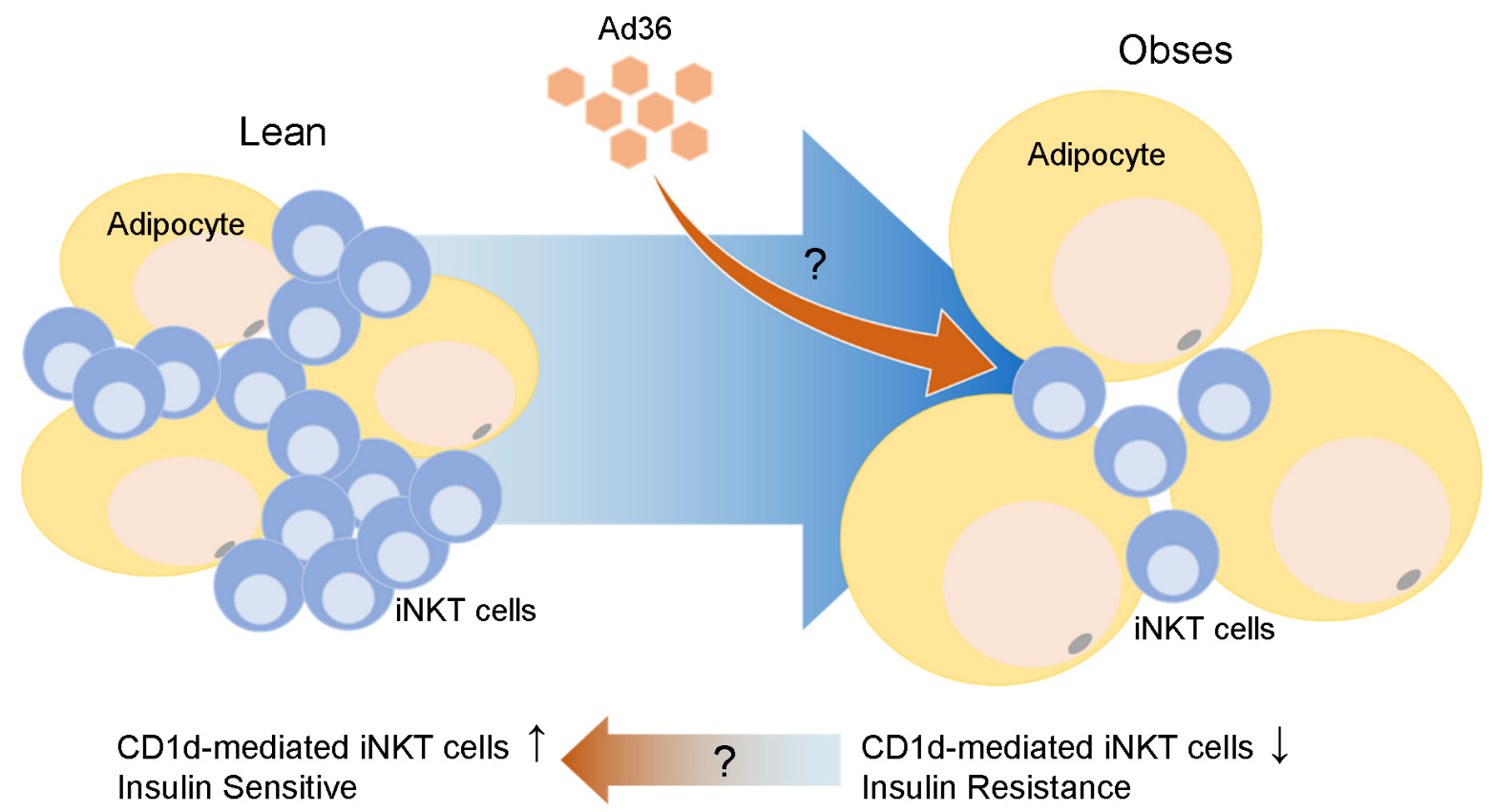

Figure 1. Diagram: Correlation of Adipocyte and iNKT cells in Adipose Tissue. The amount of iNKT cells in adipose tissue was reduced in obese status. If Ad36 infection may increase iNKT cells, it can improve insulin resistance. 
macrophage와 NKT cells이 이러한 질병의 원인으로 부 각되면서 이에 대한 많은 연구 결과들이 밝혀지고 있다 $(3,4)$.

소개하는 논문의 저자들은 지방조직에 존재하는 면역 세포들 중에서 iNKT cells에 초점을 맞추고 있으며, 직접 적인 iNKT cells의 작용이 인슐린 저항성의 발생 유무를 결정함을 보여주고 있다 (1). 특이한 T cell population 중 하나인 iNKT cells은 invariant $\mathrm{T}$ cell receptor인 Va24Ja18 (사람) 또는 $\mathrm{V} \alpha 14 \mathrm{~J} \alpha 18$ (마우스)가 $\mathrm{V} \beta 11$ (사람) 또는 $\mathrm{V} \beta 7$, $\mathrm{V} \beta 8.2, \mathrm{~V} \beta 2$ (마우스)와 함께 발현되어 있으며, 비만인 지 방조직에서는 상대적으로 그 수가 감소하는 현상을 보 여준다 $(5,6)$ (Fig. 1). 이전까지의 논문이 iNKT cells의 존 재 유무에 따른 대사관련 현상에 초점이 맞추어져 있었 다면, Schipper 등은 iNKT cells과 $\mathrm{CD} 1 \mathrm{~d}$ 와의 상호작용으 로 인해 발생하는 인슐린 저항성과의 관계를 집중적으 로 연구하였다. 저자들은 iNKT cells이 non-classical MHC molecule인 CD1d를 통해 제시된 외부항원, 특히 lipid 항 원을 인지한다는 사실에 착안하여 (7), $\mathrm{CD}^{-/-}$mice, $\mathrm{iNKT}$ cells depletion mice $\left(\mathrm{J} \alpha 18^{-/}\right)$, anti- $\alpha \mathrm{NK} 1.1$ antibody-mediated NKT cell depletion mice와 같은 다양한 iNKT cell depletion 동물모델을 이용하여, wild type (WT) mice보다 인슐린 저 항성이 더 많이 발생되는 것을 확인하였다. 특히, $\mathrm{CD}^{-1-}$ mice를 이용한 in vivo 실험에서는 insulin-sensitizing adipokine인 adiponectin의 발현 정도가 감소하고, 반대로 insulin-desensitizing adipokine인 leptin의 발현 정도는 증가 하는 것을 발견하여, CD1d-mediated iNKT cells이 존재하 지 않을 때 발생되는 인슐린 저항성의 원인이 지방조직 에서 분비되는 국소적인 adipokine의 분비양상 변화 때문 이라는 것을 증명하였다. 또한, human SGBS preadipocytes, mature adipocyte, primary subcutaneous adipocytes를 이용하 여 human adipocyte에서도 CD1d가 발현되며, adipocyte 자 체가 iNKT cells의 기능을 조절하는 lipid 항원제시 세포 (antigen presenting cells, APCs)로 작용할 수 있다는 사실 을 발견하였다. 이러한 연구 결과를 바탕으로 Schipper 등은 adipocyte가 직접적으로 lipid 항원을 제시하는 APC 로써 작용하며, 이러한 작용이 $\mathrm{CD} 1 \mathrm{~d}$ 를 통해 전달되고, 결과적으로는 지방조직과 iNKT cells이 작용하여 면역학 적 신호전달과정을 조절한다는 새로운 사실을 증명하였 다. $\mathrm{Ad} 36$ 은 다양한 동물(마우스, 닭, 원숭이) 등에 감염 되면 adiposity를 증가시키지만 역설적으로 혈액 내의 glucose 및 인슐린 농도를 감소시키는 등 인슐린 민감성
을 증가시키는 특이한 현상을 보이는 것으로 알려져 있 다 $(8,9)$. 또한 $\mathrm{Ad} 36$ 의 항체를 가진 사람들 역시 BMI level은 높으나 혈액 내 glucose의 농도는 낮아지는 등 glycemic control이 개선되는 결과를 보여주고 있다 (10, 11). 이러한 연구 결과들은 유전적, 환경적 요인과 개인별 식습관을 비만 유발 요인으로 생각하는 기존의 지식과 더불어, 바이러스 자체를 새로운 비만 유발 요인으로 발 견했다는 점에서 새로운 패러다임의 변화를 주었다고 할 수 있다. 본 연구팀의 이전 연구 결과에 따르면, $\mathrm{Ad} 36$ 감염이 지방조직에서 분비되는 $\mathrm{MCP}-1$ 의 양을 증가시키 고, 이에 따라 macrophage가 지방조직으로 침투하게 되 며, 이러한 침투에 의해 지방조직에 염증이 발생하였다 (12). 그러나 MCP-1 knock out 마우스는 바이러스 감염에 의해 유도되는 염증반응이 일어나지 않을 뿐만 아니라 $\operatorname{Ad} 36$ 감염에 의해 나타나는 adiposity 증가 및 glycemic control 개선 효과 역시 일어나지 않았다 (12). 이러한 연 구 결과는 결국 바이러스에 의해 유도되는 염증이 비만 유도 및 glycemic control 개선에 필요함을 시사하고 있고, 특정 염증 반응은 오히려 대사질환 발병을 억제하는 순 기능도 있음을 말해 주고 있다.

하지만 앞서 언급한 Ad36 감염에 의한 glycemic control 개선 효과에 대한 세포면역학적인 신호전달 기전은 더 많은 연구가 필요한 것이 사실이다. 따라서 본 연구팀은 본 논문의 저자들이 밝힌 지방조직에 존재하는 $\mathrm{CD} 1 \mathrm{~d}-$ mediated iNKT cells이 이에 대한 해답을 얻는 중요한 열쇠가 될 가능성이 충분하다고 생각하고 있다. 소개한 논문을 근거로 하면, $\mathrm{Ad} 36$ 감염이 $\mathrm{MCP}-1$ 을 통해 macrophage의 지방 조직으로의 침투 조절에 작용뿐만 아니라 직접적 또는 간접적으로 iNKT cells에도 영향을 주게 되 고, 이로 인한 변화가 대사 조절에 관여한다는 가설을 세 워 볼 수 있다(Fig. 1). Ad36에 의한 serum lipid profile 개 선 현상과, 정상적인 $\mathrm{iNKT}$ cells이 존재하지 않는 $\mathrm{CD}^{-1}$ mice에서 관찰되는 인슐린 저항성 현상을 통합적으로 연 구 및 분석할 수 있다면, 바이러스에 의해 유도되는 염증 과 대사 조절 및 면역세포 사이에서 유발되는 새로운 면 역신호전달기전이 밝혀질 수 있을 것이라 예상된다.

\section{참 고 문 헌}

1) Schipper HS, Rakhshandehroo M, van de Graaf SF, Venken K, Koppen A, Stienstra R, et al. Natural killer T cells in adipose 
tissue prevent insulin resistance. J Clin Invest 2012;122:3343 -54 .

2) Hotamisligil, Shargill NS, Spiegelman BM. Adipose expression of tumor necrosis factor-alpha: direct role in obesity-linked insulin resistance. Science 1993;259:87-91.

3) Wentworth JM, Naselli G, Brown WA, Doyle L, Phipson B, Smyth GK, et al. Pro-inflammatory CD11c+CD206+ adipose tissue macrophages are associated with insulin resistance in human obesity. Diabetes 2010;59:1648-56.

4) Wu L, Van Kaer L. Natural killer T cells and autoimmune disease. Curr Mol Med 2009;9:4-14.

5) Lynch L, O'Shea D, Winter DC, Geoghegan J, Doherty DG, O'Farrelly C. Invariant NKT cells and CD1d(+) cells amass in human omentum and are depleted in patients with cancer and obesity. Eur J Immunol 2009;39:1893-901.

6) Lynch L, Nowak M, Varghese B, Clark J, Hogan AE, Toxavidis $\mathrm{V}$, et al. Adipose tissue invariant NKT cells protect against diet-induced obesity and metabolic disorder through regulatory cytokine production. Immunity 2012;37:57-87.
7) Brigl M, Brenner MB. CD1: antigen presentation and T cell function. Annu Rev Immunol 2004;22:817-90.

8) Dhurandhar NV, Geurts L, Atkinson RL, Casteilla L, Clement $\mathrm{K}$, Gerard $\mathrm{P}$, et al. Harnessing the beneficial properties of adipogenic microbes for improving human health. Obes Rev 2013. [Epub ahead of print]

9) Atkinson RL, Dhurandhar NV, Allison DB, Bowen RL, Israel $\mathrm{BA}$, Albu JB, et al. Human adenovirus-36 is associated with increased body weight and paradoxical reduction of serum lipids. Int J Obes (Lond) 2005;29:281-6.

10) Krishnapuram R, Dhurandhar EJ, Dubuisson O, Kirk-Ballard $\mathrm{H}$, Bajpeyi S, Butte N, et al. Template to improve glycemic control without reducing adiposity or dietary fat. Am J Physiol Endocrinol Metab 2011;300:E779-89.

11) $\mathrm{Na} \mathrm{HN,} \mathrm{Nam} \mathrm{JH.} \mathrm{Infectobesity:} \mathrm{a} \mathrm{new} \mathrm{area} \mathrm{for} \mathrm{microbiological}$ and virological research. J Bacteriol Virol 2011;41:65-76.

12) $\mathrm{Na} \mathrm{HN}$, Nam JH. Adenovirus 36 as an obesity agent maintains the obesity state by increasing MCP-1 and inducing inflammation. J Infect Dis 2012;205:914-22. 